\title{
Audio intertextuality in modern advertising text
}

\author{
Marina Terskikh ${ }^{1, *}$ \\ ${ }^{1}$ Faculty of Philology and Media Communication, Chair of General and Applied Linguistics, Dostoevsky Omsk State University, 644053 \\ Omsk, Russia
}

\begin{abstract}
The article is devoted to the study of audio intertextuality in modern advertising discourse. Despite the researchers' increased interest in the problem of intertextual interaction, the issue of the functioning of the intertextuality mechanism in advertising, including social advertising, is still not fully covered, especially, since the advertising field is dynamic and provides extensive new material for research every day. The author pays special attention to the functional yield of audio intertextuality in advertising. As the basic functions of audio intertextual inclusions in the discourse of commercial and social advertising, the author identifies the attractive and aesthetic functions as the most significant and regularly realized; as secondary - playful and persuasive. Russian and foreign commercials serve as the material for the study. The method of intertextual analysis is used as fundamental. It consists in establishing the relations of derivation between texts and analyzing the formal and semantic transformations of text units and the text as a whole.
\end{abstract}

\section{Introduction}

Intertextuality can be attributed to one of the most relevant and popular areas of the humanities, since this concept is in sync with the modern era. At the time of World Wide Web, we are increasingly confronted with citations, references to authoritative sources, which often become phraseological units, classical works, films, aphorisms, etc. Consciousness of a modern person has acquired a mosaic shape, where various fragments of phrases and concepts intertwine. Considering this, the interest of researchers in the study of the concept of intertextuality in various types of discourse does not fade [1-5].

According to the theory of foreground intertextuality, intertextuality is understood as the specific quality of certain texts containing markers of intertextual interaction. We consider the appeal to the intertextuality resources as a creative tool aimed at increasing the effectiveness of the advertising message due to nonstereotyped presentation of socially significant information, updating knowledge and ideas important for representatives of the linguocultural community related to the past cultural experience, increasing the text's mnemonic potential.

In terms of the semiotic approach, the text is perceived as a policode system; therefore, we study not only verbal phenomena as a precedent, but also paintings, sculptures, architecture, and music.

As a rule, the intertextual analysis is carried out on the material of verbal or visual citation: researchers note that "creolized advertising appears as a dicode text containing verbal and visual imageries" [6, p. 129]. At the same time, one can speak of the increased interest of foreign researchers in the role of background music in advertising texts, including in the terms of intertextuality [7-14].
In this article, we would like to draw attention to the creative affecting potential of audio codes in commercial and social promotional videos, since quite often music is used as an intertextual basis of an advertising message, with or without verbal component.

The purpose of the research presented in this article is to study the audio semiotic codes used as prototext when creating advertising messages. In total, more than 70 commercial and social promotional videos were analyzed. The method of intertextual analysis is used as fundamental. It consists in establishing the relations of derivation between texts and analyzing the formal and semantic transformations of text units and the text as a whole.

\section{Research results}

\subsection{Audio intertextuality in the discourse of commercial advertising}

Media music has an important role, since it can complement the text with associations and symbols, attract consumers' attention, generate emotions, be as a pleasant background and even be a synthesized music and vocal advertising carrier by being an advertising jingle.

Relatively long promotional videos are created for a detailed narration of the product as well as to call to buy it immediately. Among them are, for example, TV shops and large informational advertising programs. A long rhythm-melodic melody is often used in them as a psychodramatic tension (to boost the hype).

First of all, the mass manifestation of commercials on the radio and TV is associated with a mobile and bright media genre of an independent commercial (its usual

\footnotetext{
Corresponding author: terskihm@mail.ru
} 
timing is 10-120 seconds). Independent commercials even took an important place in shaping the aesthetic taste and scale of humanistic values of listeners and viewers. Indeed, nowadays there is a whole layer of social advertising in this media genre, calling for respect for nature, patriotism, healthy lifestyle, sympathy, and care for the sick and children. And many commercials have become a phenomenon not only of a financial undertaking, but also acquired the features of cultural, entertaining, artistic mini-production of media associated with classical art. It is no coincidence that folklorization of advertising slogans and humming songs is taking place, as well as large-scale contests of caterers and festivals are organized similar to the American Clio Awards, which celebrated its 55th anniversary using commercials with classical music compilation (Mozart, Rossini and Johann Strauss).

$\mathrm{N}$. Efimova notes that the use of classical music in domestic commercials can often be considered as not entirely successful experiments. She finds the use of classical themes and rearranged versions of lacking culture "postmodern games with intertext of the past" inappropriate and rightly doubted in the relevant combination of beer commercials and music from the finals of the Tchaikovsky First Piano Concerto, therapeutical zirconia bracelets and famous Boccherini Minuet, superglue or contraceptive candles and Mozart. "For example, the soundtrack for zirconium bracelets is Luigi Boccherini's computerized rhythmic sound of the "Minuet". Pyshka margarine background music is an incorrect arrangement of a fragment from A. Dvorak's Humoresque (the ironically humorous aspect is removed in the arrangement). The Klinskoe beer commercial uses shallow arrangements of the well-known First Concerto of P.I. Tchaikovsky. The theme of the final "Viydi, viydi Ivanku" (Come, come Ivanku) is presented in the hard rock style, in all likelihood intended to symbolize the come of "Vankas" infused with beer, etc. From the latest examples we can name a very superficial arrangement of the famous melody "To Elise" by L. Beethoven in the Tropicana juice commercial. Such use of the Russian musical classical heritage is nothing but disrespect for its spiritual heritage, obvious flirting with the public, and ultimately - total irresponsibility [15, p. 99].

It should be noted here, however, that a compilation of classical concert, opera or any other music can be presented in commercials quite worthy: citation of the main theme of the western "The Magnificent Seven" (1960, composer Elmer Bernstein) in many television and radio commercials of Marlboro cigarettes (1970-1980s), accompanying the brave cowboy, is an obvious example.

Musical and sound design of commercials in theory is studied rarely as a system. One can, for example, refer only to some specialized works of German authors Sigmund Helms or Hildegund Leo, who consider music in advertising of electronic mass broadcasting (in particular, media advertising), the reference book by American Walt Woodward and the Danish collection of scientific articles on music in commercial advertising. Furthermore, a comprehensive system of sound or musical-sound design is an important audio component of the commercial, aimed at creating the most profitable "market" image of a product and being a leading element of the psychological impact on the viewer or listener. For example, the features of the dramatic connection between image and sound, built on psychographic and neurophysiological effects lies at the core of professional commercials. Associative thinking is important here, as well as knowledge of the symbols of psychoanalysis, and handling civil, national, parental or friendly motives, and a subtle sense of humor, and possession of the basics of human affects, and the theory of biorhythms.

In the course of a social survey, it was revealed that the audio format of the intertext was found in $92 \%$ of cases by testees. This is one of the most easily defined intertextuality tools that we have analyzed. High recognition allows increasing the impact of commercials on consumers. Moreover, the audio format was more memorable, so the associative array from a specific song to a specific product is built and fixed in minds of the addressees.

A bright example of audial intertextuality is the "Orbit" commercial "Time to Speak". The text uses a well-recognized composition from the film "Ivan Vasilyevich Changes Profession" - "Happiness suddenly knocked on the door in silence." In this case, the prototext is precisely the tune, and the text of the song is changed, translated into English and broadcast on screens as subtitles in Cyrillic (pic. 1-2).

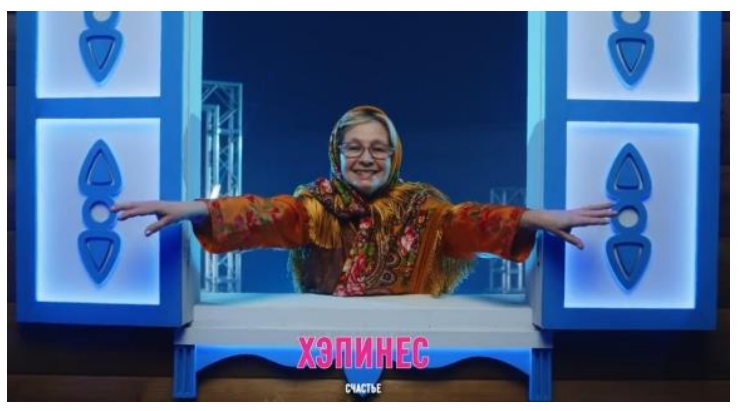

Pic. 1. "Orbit" commercial "Time to Speak"

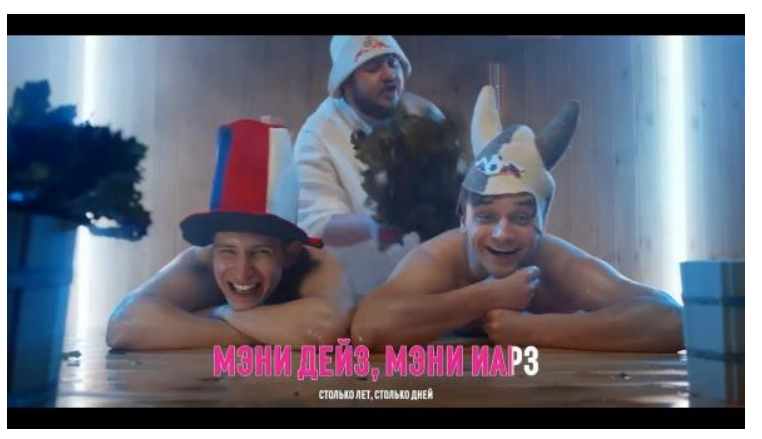

Pic. 2. "Orbit" commercial "Time to Speak"

Saving the tune series without changes often does not carry a semantic load, performing more energetic and aesthetic functions. But there are vivid examples of exceptions.

The newly increased interest in the rock band Queen, caused by the release of the full-length film "Bohemian Rhapsody", is also reflected in the advertising discourse. Extraordinary video dedicated to the beginning of cooperation between two companies "Johw Lewis" 
(hosiery) and "Waitrose" (cookery) emphasizes the fusion of seemingly incompatible things with the help of the Queen song "Bohemian rhapsody". Children, bored playing classical music on violins (pic. 3), suddenly decide to perform something more cheerful and begin to sing this song (pic. 4). In addition to audio borrowing, there is also a visual one, because children in their own way perform scenes from the music video.

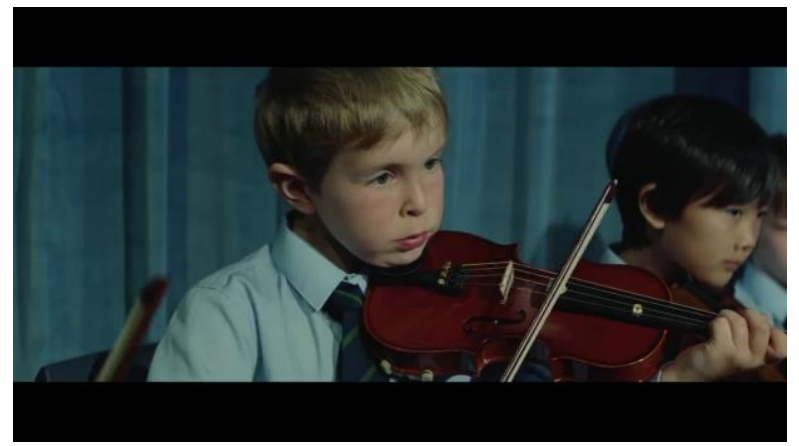

Pic. 3. "Johw Lewis" and "Waitrose" commercial

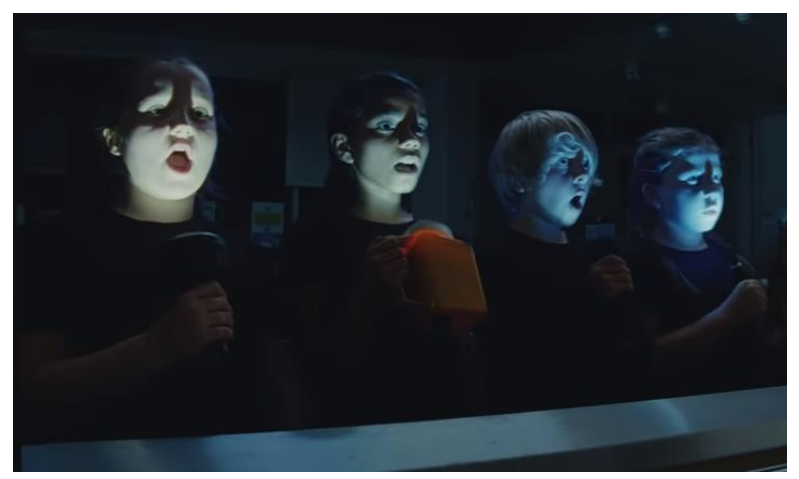

Pic. 4. "Johw Lewis" and "Waitrose" commercial

In this case the song is the manifestation of the fusion of the extraordinary, incompatible. The song itself has repeatedly been the object of controversy because of the multiple inclusions of various seemingly incompatible genres. The same thing happened with the merger of two completely different companies, which, it seemed, could not be merged, as they exist in completely different areas, representing products of different product categories. Thus, the song also acts as a plot-forming element, and as a whole acts as a symbol of cooperation, union.

Audio intertextuality performs an unusual function in the Ford Kuga car commercial. A song from the cartoon "The Bremen Town Musicians" is the tune series. It plays while a young family with children travels in a comfortable and safe - according to the story - car and sings a familiar song. In this video, the song is the symbol of a friendly family, which can go on an exciting journey in the advertised car. The song refers to the plot of the cartoon, where friendly Bremen town musicians rode on a horse wagon to meet adventures.

The use of a certain tune series is the recognition and popularity of media music material, music and sound brand, a sound "face" of a product. Of course, in commercials, this tune series is often based on original music specially written by the composer (for consumers, this music often remains anonymous). However, we often encounter explicit music compilation in commercials, such as, for example, in the case of the Hexoral throat medicine commercial popular in 2018, in which Philipp Kirkorov plays the main role (pic. 5). The background music of the commercial is recently released Kirkorov's song "The color of the mood is Blue". In this video, the words in the song are changed, but the key phrase is quoted unchanged. Due to the inclusion of this song and the performer in the commercial, the memorability and "viral nature" of the commercial and the product is increased, since the single itself was originally viral.

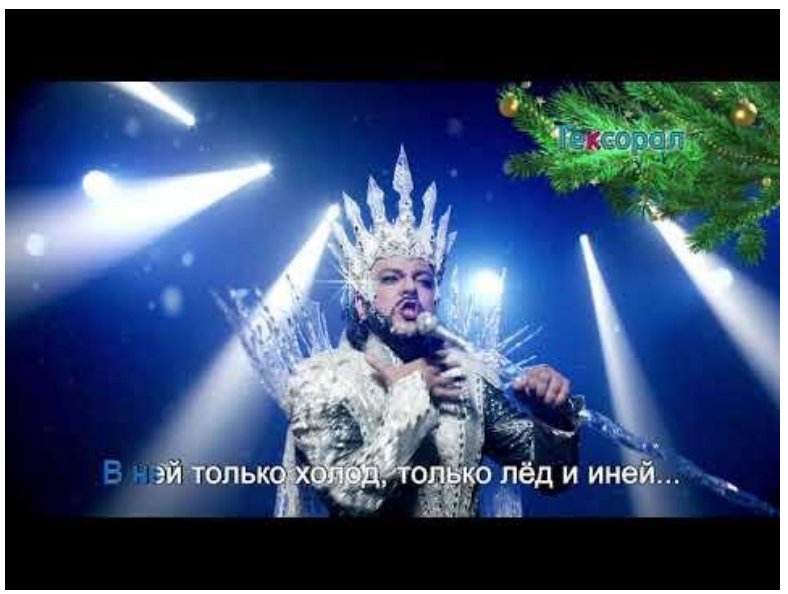

Pic. 5. Hexoral throat medicine commercial

It was decided to play with the same tune series and singer Philipp Kirkorov in the "Svyaznoy" commercial and the song is modified into "The color of the mood is blue, the color of the mood is black," which emphasizes the possibility of choosing the favorite color of the advertised smartphone (pic. 6).

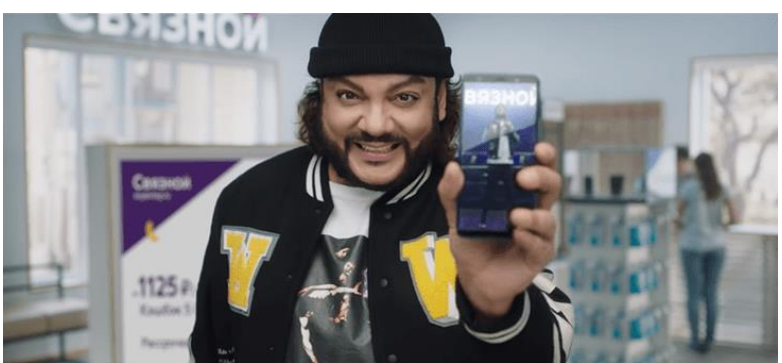

Pic. 6. "Svyaznoy" commercial

The music theme brand will certainly be associated with a particular product after multiple listening. And afterwards, potential buyers will only have to hear it (on air or even not), so that an image of one product or another would appear in their minds.

In such manner KFC commercials are created. They include a recognizable viral audio component in the video. The melody and keywords of the songs are borrowed, but the meaning of the text is still undergoing some changes. For example, the advertisers of this brand used the songs of the band "Banderos" ("Columbia Pictures does not represent ..."), the group "Ruki vverkh", rapper Serega. The same tune series sound in fast food restaurants. Therefore, every time these melodies will 
awaken in consumers memories of the cuisine offered by the restaurant.

An independent song can be the basis of the commercial, which has only an indirect association with its plot and the represented goods. For example, in the commercial for the fragrance "Miss Dior", directed by Emmanuel Cossu, the song Chandelier performed by Sia was used in the behind-the-scenes sound as an image of the emotional impact on the characters of the promotional video of famous French perfumes.

\subsection{Audio intertextuality in the discourse of social advertising}

Audio intertextual code is also regularly used in social commercials.

\section{Mad World.}

To the celebration of the International Children's Day, which is celebrated on November 20, the International Children's Fund released a social video where the Wuppertaler Kurrende boys' choir sang the song "Mad World" by the band "Tears For Fears". In the plot of the video every three seconds, one of the participants left the stage until there was only one performer left. The action symbolized the fact that every three seconds one child dies and many children do not live to the age of five. The reasons for this are different: hunger, lack of clean water or lack of antiviral vaccines. The video encourages going to the web-site of the international organization for the protection of children and making a donation.

\section{I'll Be Home for Christmas.}

The British organization FIA Foundation together with the M \& C Saatchi agency released a social video with the popular slogan "Don't text and drive". The commercial used the song "I'll Be Home for Christmas", which was written in 1943 by Kim Gannon.

During the Second World War, the words "I will be home for Christmas, even if only in my dreams" had a completely different meaning. The text was originally dedicated to soldiers abroad who dreamed of meeting Christmas at home. Now the commercial creators used the Christmas song for the social video about safe driving.

A girl texts her father, who is driving home according to the plot of the video. Messaging leads to a fatal outcome: a man gets into an accident and then dies.

\section{Casta Diva.}

Radio Choise FM has released a social video against violence. A bullet piercing and breaking various products such as: a glass of milk, raw egg, apple, ketchup, bottle of water, and watermelon unites scenes changing each other. All this action happens to the melody "Casta Diva" from Bellini's opera "Norma". The combination of sublime aria and slow motion is fascinating. The beauty of destruction fills the entire scene. Destroyed object becomes art. The idea of the video is clarified only in the final scene, where the bullet flies towards the head of a child. The inscription-slogan appears to combat violence "Stop the bullets. Kill the gun". The aesthetics of destruction gives way to tragedy when it comes to people.

\section{Time to say Goodbye.}

The international organization IFAW (International Fund for Animal Welfare), which aims to fight for the preservation of certain species of endangered animals due to human actions, has released a social video in defense to save the whale population. In 2002, the creators of this video received an award for a creative idea and a talented implementation. The video is accompanied by the song "Time to say Goodbye" performed by Sarah Brightman and Andrea Bocelli. Throughout the video, the whales perform the above-mentioned song, and only in the final scene there is an outcome: "Time to say Goodbye: Norway and Japan are whaling again."

\section{Conclusions}

Since the specific features of commercials are related to the performance of narrow-pragmatic tasks, the key is the question of the functions that intertextual inclusions, including auditory, perform in the advertising message. In the article "Intertextuality tools in the discourse of social advertising" [16], we noted that the use of intertextuality tools in commercials text performs, from our point of view, a number of functions, among which we consider attractive (attracting attention) and persuasive (exposure). Among the secondary functions we singled out aesthetic (in this sense, intertextual indexes can be considered as a source of advertising creative), human, or game (in the process of decoding an advertising message, the recipient is included in a kind of intellectual game, the result of which often is the pleasure from solving the riddle) and delimitative (choice of the phenomenon according to the specifics of the recipient - addressing the advertising message to a specific reference group that can identify intertextual inclusion and adequately understand the author's intention).

If we talk about the functional load of audio intertextual codes, then the attractive and aesthetic functions should be mentioned as fundamental: music as a type of art certainly attracts attention and contributes to an increase in the aesthetic potential of the advertising message. In addition, as we have seen, the advertiser's desire to "play" with a famous song or melody is at the core of an appeal to musical works. The use of a musical work in an advertising message can be accompanied by the attraction of a singer in an advertising video, which allows us to speak of an appeal to the authority of a famous person and the persuasive function of the audio intertextual code.

The reported study was funded by RFBR and Government of Omsk region according to research project № 18-412-550001.

\section{References}

1. Zengin M. An Introduction to Intertextuality as a Literary Theory: Definitions, Axioms and the Originators. Pamukkale University Journal of Social Sciences Institute. 1. 299-326 (2016). doi:10.5505/pausbed.2016.96729.

2. Jiménez G., and Elías R. Cinema and Advertising: 
Intertextuality in Volkswägen Campaigns. Arte, Individuo y Sociedad. 25 (1). 153-167 (2013) doi:10.5209/rev_ARIS.2013.v25.n1.41170.

3. Akasheva T.V., Pesina S.A., Rakhimova N.M., and Zemlyanukhina E.V. Interpreting cognitive strategies of intertextual inclusions in belles-lettres discourse (based on E. Jelinek's prose literature). Cognitive Linguistics. 2. 5-10 (2016).

4. Chernyavskaya V.E. Linguistics of Text: Polycode and Interdiscoursivity, Intertextuality. Moscow, LIBROKOM publ., 248 p. (2009).

5. Rakhimova N.M. Cognitive strategies of precedent text interpretation in the context of work of art. Philological Sciences. Issues of Theory and Practice. 2 (9). 139-142 (2011).

6. Vysotskaya I.V. Precedentness as a mean of effective communication in advertising. Critique and Semiotics. 125-137 (2014).

7. Abolhasani M., Oakes S., and Oakes H. Music in Advertising and Consumer Identity: The Search for Heideggerian Authenticity. Marketing Theory. 1-18 (2017). doi:10.1177/1470593117692021.

8. Harrison K. Musical Intertextuality in Indigenous Film. In Chapter 8 in Return to the Land of the Head Hunters: Edward S. Curtis, the KwakwaKa'Wakw, and the Making of Modern Cinema. 212-231 (2014).

9. Zander M.F. Musical Influences in Advertising: How Music Modifies First Impression of Product Endorsers and Brands. Psychology of Music. 34 (4). 465-480. doi:10.1177/0305735606067158.

10. Hung K. Narrative Music in Congruent and Incongruent TV Advertising. Journal of Advertising. 29 (1). 25-34 (2000).

doi:10.1080/00913367.2000.10673601.

11. Buda A. In the postmodern mirror: Intertextuality in Angels and Insects by Antonia Susan Byatt. Journal of Language and Cultural Education. 3(2). 66-70 (2015). doi:DOI: 10.1515/jolace-2015-0015

12. Bullo S. Investigating intertextuality and interdiscursivity in evaluation: The case of conceptual blending. Language and Cognition. V. 9, issue 4. 1-19 (2017). doi:doi:10.1017/langcog.2017.5

13. D'ngelo F.J. The Rhetoric of Intertextuality. Rhetoric Review. 29(1). 31-47 (2010). doi:10.1080/07350190903415172

14. Palencia-Lefler M. Film music in advertising: An intertextual Approach. Journal of Marketing Communications, DOI:10.1080/13527266.2018.1514318

15. Efimova N.N. The sound in the air (Moscow, 2015). $145 \mathrm{p}$.

16. Terskikh M.V. Tools of Intertextuality in Discourse of Social Advertising. Nauchnyy dialog. 9. 69-80. DOI: 10.24224/2227-1295-2017-9-69-80. 